Cell International Journal of Industrial and Business Management (ISSN:2572-8423)

\title{
Problems and solutions with China's P2P lending regulation
}

\section{Hang Yin} Here we find out the problems and possible solutions with China's P2P lending regulation on the basis of above chapters' analysis and conclusions. The main problems and corresponding solutions are as follows: •China's current regulation pattern of institutional regulation is not effective, creating legal blankness and blurs. China is supposed to implement the functional regulation system as an alternative. $\bullet$ It is reasonless to assign local governments to regulate $\mathrm{P} 2 \mathrm{P}$ lending within respective jurisdictions, as $\mathrm{P} 2 \mathrm{P}$ lending has the nature of revenue localization but risk nationalization. Banking regulatory bureaus that are vertically managed by the central government are more suitable to become local regulators for P2P lending. ${ }^{\circ}$ China's P2P lending industry association still has a great distance to become a real industry self-regulation organization like P2PFA in the UK, since that it has a too low coverage rate. Eligible platforms should be required to join in the industry association to improve the association's management effectiveness. Establishing a new $\mathrm{P} 2 \mathrm{P}$ lending database is a waste of current resources. The $\mathrm{PBC}$ credit reference center is a relatively well-developed credit review system. If $\mathrm{P} 2 \mathrm{P}$ platforms are permitted to access to the PBC credit reference system, there is no need to invest more financial and material resources in founding a new database. Regulation on securitization in P2P lending industry is ignored by the regulators. $\mathrm{P} 2 \mathrm{P}$ lending securitization is an inevitable trend, which needs scientific guidance and standardization. The problems of risk responsibility subject, information disclosure, and excessive securitization should be paid more attention when designing related mechanisms. $\cdot$ Rules about risk reserve mechanism are omitted by the regulators. Real risk reserve funds can protect investors to some extent and will not result in liquidity risks for platforms. A qualified risk reserve mechanism should be independent, with limited protection, and full information disclosure.
Keywords: Problems, solutions, China's P2P lending regulation

${ }^{*}$ Correspondence to Author:

Hang Yin

E-mail: aigirl92@163.com

How to cite this article:

Hang Yin.Problems and solutions with China's P2P lending regulation. International Journal of Industrial and Business Management, 2017; $1: 3$.

\section{eSciencePublisher}

eSciPub LLC, Houston, TX USA. Website: http://escipub.com/ 
This paper is going to discover the problems existing in China's regulatory system and then provide corresponding suggestions to solve the problems. The problems and solutions are focused on the Draft Measures, which is the main basis for China's next step of P2P lending regulation.

\section{Regulation pattern}

The US and the UK both implement the functional regulation, which means that as long as institutions are employing related businesses, they are all regulated by corresponding regulations (Harvard, 2014). By contrast, China implements institutional regulation rather than functional regulation. There exists the opportunity for regulatory arbitrage, since that if a financial institution does not register on the specific type of business, it will come into a legal gap and do something that is supposed to be forbidden.

In China, there are many financial institutions that absorb deposits and make loans, but they do not call themselves banks and do not apply bank licenses (Guo \& Xia, 2014). They are not supervised by bank regulations. Only when they are in trouble and bring financial market even the whole society adverse impacts, they will be punished. However, this after-event supervision is not that smart and effective. There are also many institutions actually carry out businesses include trust, guarantee, even securities, but change a name and operate without worries of strict regulations. If China still implements the institutional regulation, one possible result could be that $\mathrm{P} 2 \mathrm{P}$ lending platforms declare that they are not P2P to avoid regulation.

Certainly, the Draft Measures indeed show the regulatory authorities' expectations to implement the functional regulation. Nevertheless, there is still a long way for real functional regulation implemented in China under its current regulatory system (Huang, 2015). But it is worth expecting the new reform plans for China's financial regulatory system.

\section{Local regulators}

According to the Draft Measures, the CBRC is responsible for making P2P lending industry's unified rules, and local governments are respon- sible for related business compliance and risk treatment works within respective jurisdictions. However, P2P lending has a nature of globality and is not fit for decentralized regulation.

The CBRC had a large scale of organizational adjustment in January 2015, including set up an inclusive finance department on the base of financing guarantee department (CBRC, 2016). The new department is responsible for financing guarantee, small loans, and online lending. The other two industries are regulated by a decentralized pattern of regulation system, which means that the central competent departments make rules and provincial governments execute daily supervision. P2P lending was assigned to the same department with them, predicting the same mode of regulation will be forced.

Nevertheless, financing guarantee and small loans are industries that have strong local finance properties. Small loans companies are restricted to operate business only in registered places. Although financing guarantee companies are allowed to set up branches cross-regions, the high threshold always deters the regional expansion (Huang, 2015). On the contrary, P2P lending industry is not restricted by regional problems, being able to absorb funds and allocate them all over the country conveniently and less costly. The business scope of P2P lending is countrywide, but the tax paid and employments promoted are mainly concentrated in places of registration.

This character of globality will also lead to a vicious result of revenue localization but risk nationalization. The revenue from P2P lending mainly go to local stakeholders' pockets, but the potential risk is borne by the whole country's stakeholders. For this reason, P2P lending has the property of regional negative externality. The inevitable result of local governments managing such enterprises is the undue emphasis on economic development but negligence on real regulation. Local governments have incentives to promote economic growth and increase tax revenues but not enough incentives to regulate. Attracting investment and facilitating local financial institutions to grow stronger and larger is always the first duty of local governments.

From a wider range of perspective, China is a 
large country, which needs local governments' promotion to carry out work more swimmingly. For this reason, decentralization is a good choice and also an important experience to realize rapid economic development. Meanwhile, another significant experience for China is to practice vertical management in fields that have externalities or related to macro stability, fair \& just problems and so on (Sun, 2011).

Vertical management can remit the negative influence from cutthroat competition. From industries like territorial resources, medical treatments, and foods security to financial industries like banks, securities, and insurance, they are all managed vertically by central governments. Financial institutions have the properties of information asymmetry and opacity, influencing consumers' legal rights. They also have systemic importance and high infectivity, affecting the macro economy's stability. Therefore, central governments should remain at the heart of the financial industry.

Admittedly, excessive centralization ignores local governments' responsibilities in dealing with local financial risks and is not fit for all financial industries, especially the financing guarantee and small loans. Nonetheless, P2P lending has essential differences with financing guarantee and small loans. As a result, P2P lending is supposed to be regulated vertically. A possible top-level design is to effectively apply banks' regulatory system, which means that the banking regulatory bureaus that are vertically managed by the CBRC in every province rather than local governments should be assigned as regulators to carry out daily regulation.

\section{Industry association}

China's Internet finance has a marked growth rate, leaving the regulations behind. Therefore, the national industry association has bright prospects in regulating the whole industry. However, the CIFA has a low coverage rate (with only 39 out of 2349 platforms), not realizing self-regulation management full coverage. As a self-regulation organization, comprising only a small part of the whole industry will not have the power to manage the industry. One reason is that nonmember institutions do not have the responsibilities to obey the association's rules. A low coverage rate will definitely have a negative impact on association's management effectiveness. By contrast, full coverage of P2PFA in the UK makes it have stronger speaking right among the industry.

The association's legal authorization presents a challenge to the ideal situation of full coverage. It is a voluntary choice for the companies to decide their join or exit of the association. Similarly, the China Microcredit Companies Association also has a low coverage of about $3 \%$, with 256 members among 9000 homogenous companies (CMCA, 2016). The Draft Measures and other rules neither require $\mathrm{P} 2 \mathrm{P}$ lending platforms to join the association, which might lead considerable amount of companies to live outside of self-regulation. Furthermore, a vicious situation of compliant platforms joining association while nonstandard platforms not joining could come out. This consequence will be more worrying as the nonstandard companies are restricted by fewer rules.

A high threshold also poses a threat to the coverage rate of association. Although there are no definite rules on registered capital and other requirements, the current members are all platforms that have abundant capital strength. As a consequence, large platforms control the whole situation, leading to small platforms' legal rights and public interests be ignored. Even worse, the CIFA is an association with both traditional finance institutions and novel Internet finance institutions, resulting in self-regulation rules leaning toward large traditional organizations. This lies in the fact that the association's leadership is occupied largely by big traditional institutions.

The CIFA should duly balance the relationship between threshold and coverage rate. On the one hand, P2P lending industry is intermingled with the good and bad, a certain threshold is necessary to make sure the association's quality and credibility. On the other hand, the negative effects of low coverage rate should not be ignored. Department rules or higher-level laws are supposed to require eligible platforms to join in the association compulsively. An example can be referred to is that the Securities Law requires securities companies to join in the Securities Association of China (NPC, 2004).

When the mandatory requirement is executed, 
all eligible P2P lending platforms will join in the industry association. Platforms cannot use this association membership as a credit enhancement tool, as this is not an advantage over other platforms anymore. Platforms' credit enhancement behaviors are easy to misdirect investors to blindly trust in platforms on the surface rather than the essential assets. The compulsive requirement will also decrease the probability of association's rent seeking behaviors when looking for qualified members.

\section{Credit review}

China's credit review is mainly dominated by the central bank's credit reference center, rather than credit reference agencies that are popular in the US and the UK. By the end of 2014, the PBC system has recorded more than 350 million of natural persons, and 10 million of enterprises (PBC, 2015). Therefore, if P2P lending platforms can successfully access to the central bank's credit reference center, they will be more efficient and effective in terms of credit review, contributing to $\mathrm{P} 2 \mathrm{P}$ lending industry's healthy growth. Nevertheless, the Draft Measures gives an ambiguous expression and does not point out specifically that if $\mathrm{P} 2 \mathrm{P}$ lending platforms are allowed to access to PBC system.

The technical problem is not a reason for P2P lending platforms' inability to access to central bank's credit reference system. Actually, Shanghai Credit Information Services Co. Ltd. has established China's first Network Finance Credit System (NFCS). The NFCS accepts the same techniques with PBC system, which means that they can surely have a successful docking (Yicai, 2015). The only barrier for P2P lending platform entering into PBC system is its legal status. According to the Regulation on the Administration of Credit Investigation Industry, all lending institutions should be brought into PBC credit reference system (PKULAW, 2013). However, peer-to-peer lending platforms are positioned as information intermediaries rather than lending institutions. This identity increases the difficulty for $\mathrm{P} 2 \mathrm{P}$ platforms entering into the $\mathrm{PBC}$ credit system. Although the rules did not say non-lending institutions could not be included in the system, the current intersystem institutions are all lending organizations.
The Draft Measures proposes to establish a new central database for P2P lending industry. This is a bright spot of the new rules, however, if P2P platforms are permitted to access to the PBC credit reference system, there is no need to invest more financial and material resources in founding a new database. It is worth considering that P2P lending platforms should be included in PBC credit reference system though they are not lending institutions. Although P2P platforms are information intermediaries that do not need to take deposits and then make loans, they also need to investigate borrowers' credit conditions. Credit investigation is an important step for P2P lending platforms, holding the key to successful online lending. It is worth learning from the US's practice to work in support of expanding P2P lending platforms' access to government-held data (Treasury, 2016).

\section{Securitization}

Securitization is the financial process of transferring illiquid assets that have stable cash flows into liquid securities (Gallant, 2016). In the US's typical P2P lending business model, all loans are originated by platforms' issuing bank partners. P2P platforms then buy the creditor rights from banks and issue notes or certificates to investors. This shows that the US's P2P lending took the road of securitization from the start. For this reason, $\mathrm{P} 2 \mathrm{P}$ lending in the US is positioned as securities trading and is supposed to be regulated by the SEC.

By contrast, China's popular P2P lending business model does not include securities issuing. The main role platform plays is an intermediary, connecting borrowers and lenders together. However, more businesses related to securitization gradually emerge as the P2P lending industry becomes more and more complex. The own or purchased creditor rights, the secondary loan market, and ABS are all correlative businesses.

P2P securitization can accelerate assets' turnover rate, as the original illiquid assets with limited investors become liquid and can be invested by more people. However, securitization has higher requirements on platforms' financial techniques. The Draft Measures has positioned P2P lending platforms as information intermediaries, who do not need many financial techniques as financial 
institutions. Besides, the Draft Measures does not mention about securitization. China's current laws on loan securitization neither have related provisions, since that they target on banks and other traditional financial institutions rather than private lending institutions.

Securitization of P2P lending assets has a huge potential market, as it plays a key role in expanding the asset side in such rapid growing industry. Original creditors like small loans, financial leasing, and factoring companies also have the strong desires to transfer their creditor rights out of the balance sheet to buffer strict regulation requirements. For these reasons, P2P lending securitization is an inevitable trend. To guide and standardize scientifically is better than simple forbiddance. If $\mathrm{P} 2 \mathrm{P}$ lending securitization is forbidden absolutely, it will still be implemented under the table, which will lead to more serious harms to financial market and the whole society.

The followings are three main aspects that should be paid more attention when designing the related mechanisms.

(1) The subject of risk responsibility: in standardized securitization, creditor rights are transferred to the trustee, who is the subject of risk responsibility. However, most securitization businesses in P2P lending industry are not standardized ones, which make investors become the responsibility body. Related regulations are supposed to consider this responsibility body problem to give investors clear explanation.

(2) Information disclosure: current disclosure on securitization projects is not clear and complete enough. For example, most creditor rights packages in the sample platforms just describe the underlying loans curtly. Investors cannot identify and measure the original information on most basic products. Securitization can beautify the underlying assets' real quality, misleading investors to have improper expectations on products. Related regulations should strengthen securitization products' information disclosure, making sure to reflect the original underlying assets' accurate and complete information.

(3) Excessive securitization problem: a major contributing factor of the 2007 US subprime mortgage crisis came from excessive and over-com- plicated securitization. This is a warning to securitization industry in its future development, and $\mathrm{P} 2 \mathrm{P}$ lending is no exception. If the original borrowers default, all securities in following steps become rubbish. The more times original creditor rights to be securitized, the more stakeholders will be affected and the more turbulence will occur in the financial market. For this reason, limitations on excessive securitization should be considered by regulatory authorities.

\section{Risk reserve}

China does not have enough objective conditions to facilitate P2P lending platforms become pure information intermediaries in the current stage. The main reasons include the unsatisfactory credit review environment and the rigid repayment tradition. It is unfair and unpractical to let China's investors bear all the risks by themselves, thus the guarantee model is popular in China's P2P lending market. However, self-guarantee from the platforms is a risky method and has been banned by the Draft Measures. The third-party guarantee is approved, but most platforms' third-party guarantee business is always accompanied with legal risk (Wang et al., 2015). A good solution is to introduce a reliable risk reserve mechanism into P2P lending platforms.

Many P2P lending platforms among our sample platforms have already implemented risk reserve mechanisms. In the current risk reserve mode, the P2P platform set up a fund account, putting a certain proportion of loans into this account. When defaults happen, platforms will use cash in the reserve account to pay investors first. This mode of risk reserve can make up investors' certain losses, gaining industry insiders' great appreciation. However, the funds are belonged to platforms themselves, as platforms have the rights to dispose of them. Platforms use the own capital to protect investors, contradicting the Draft Measures' rule of no self-guarantee.

Risk reserve can help protect investors to some extent and increase consumers' confidence in this industry. Therefore, another mode of risk reserve can be carried out reasonably.

First, it should be explicitly stipulated that the proprietorship of risk reserve is not belonged to P2P lending platforms. Most current platforms have 
not separated risk reserve with own capital, leading to reserve misappropriation. Some platforms hand over the reserve to a third party bank and let the bank manage this fund (like Yirendai). But it is worth noting that the custody account should be implemented to the real place, or it will only become a deposit account. Zopa from the UK is a good example in terms of risk reserve. Zopa has Safeguard as the risk reserve and hands it over to an independent company to deal with. When the money funded by a contribution from borrowers has been transferred to the independent company, Zopa has lost the proprietorship of the money (Zopa, 2016).

Next, platforms cannot implement self-guarantee in the name of risk reserves. Some P2P lending platforms set up the risk reserve on the surface, but actually carry out self-guarantee (Lingyi, 2015). The proportion of borrowers' loans into risk reserve is always at $1 \%$ to $3 \%$ (from our sample platforms), which is hard to cover the platform's non-performing loans. When risk reserve is not enough, these P2P lending platforms just use their own capital to make up the remained loss. Therefore, P2P lending platforms should strictly declare that the amount of risk reserve used to protect non-performing loans is limited. Furthermore, P2P platforms should have full information disclosure on the usage of risk reserves.

\section{References}

CBRC. (2016). The State Council Issued the Plan for Promoting the Development of Financial Inclusion (2016-2020) . Retrieved 24 July, 2016, from http://www.cbrc.gov.cn/EngdocView.do?doCID=14667AC65F6444079F404024229CD810

CMCA. (2016). CMCA Member list. Retrieved 24 July, 2016, from http://www.china-cmca.org/gyxh/ hyml/

Gallant, C. (2016). What is securitization?. Retrieved 24 July, 2016, from http://www.investopedia.com/ ask/answers/07/securitization.asp

Guo, L., \& Xia, D. (2014). In search of a place in the sun: the shadow banking system with Chinese characteristics. European Business Organization Law Review, 15(03), 387-418.

Harvard. (2014). The Functional Regulation of Finance. Retrieved 23 July, 2016, from https://corpgov.law.harvard.edu/2014/06/16/the-functional-regulation-of-finance/

Huang, H. (2010). Institutional structure of financial regulation in China: Lessons from the global financial crisis. Journal of Corporate Law Studies, 10(1), 219-254.

Lingyi. (2015). China's P2P lending service industry white paper. Beijing: Oriental Press.

NPC. (2004). Securities Law of the People's Republic of China. Retrieved 24 July, 2016, from http:// www.npc.gov.cn/englishnpc/Law/2007-12/11/content_1383569.htm

PBC. (2015). Credit Reference Center Operation Report (2004-2014). Retrieved 24 July, 2016, from http://www.pbccrc.org.cn/zxzx/zxzs/201508/ f 4 e 2403544 c 942 cf 99 d 3c7 1 d 3 b $559236 /$ files/0e78bdbd53cf4ed39b25d886a16054c9.pdf

PBC. (2015). The Guidelines on Promoting the Healthy Development of Internet Finance. Retrieved 21 July, 2016, from http://www.gov.cn/xinwen/2015-07/18/content_2899360.htm

PKULAW. (2013). Regulation on the Administration of Credit Investigation Industry. Retrieved 24 July, 2016, from http://en.pkulaw.cn/display.aspx?cgid $=194035$

Sun, J. (2011). Study on the financial supervision and anti-monopoly regulation of integration of industry and finance-in view of confronting global financial crisis and mitigating domestic financial risks. Frontiers of Law in China, 6(2), 284-315.

Treasury. (2016). Opportunities and Challenges in Online Marketplace Lending. Retrieved 21 July, 2016, from https://www.treasury.gov/connect/blog/ Documents/Opportunities_and_Challenges_in_Online_Marketplace_Lending_white_paper.pdf

Wang, Y.J., Lv, H.M., and Wang, Q. (2015). Some legal suggestions on P2P lending's guarantee mode. Retrieved 24 July, 2016, from http://cn.lexology.com/ library/detail.aspx?g=6bb33156-8b7e-44f8-a44a7c43f0ba9d2b

Yicai. (2015). NFCS Solves Credit Review Problem. Retrieved 24 July, 2016, from http://www.yicai.com/ news/4569981.html

Zopa. (2016). How Zopa minimises risk. Retrieved 24 July, 2016, from https://www.zopa.com/lending/ risk-management

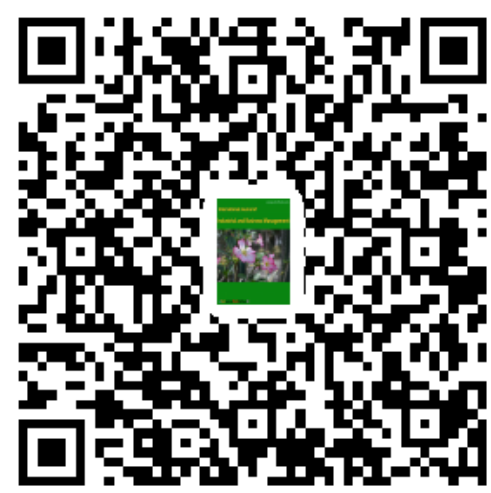

